
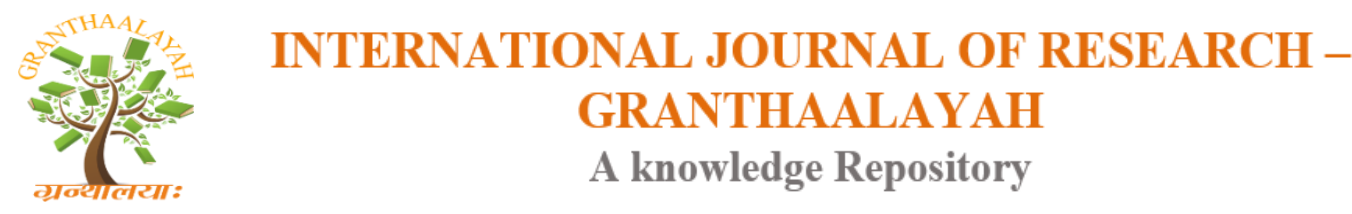

DOI: 10.29121/granthaalayah.v6.i3.2018.1492

\title{
Social
}

\section{MOTIVATION OF STUDYING WITH THE HELP OF INFORMATION SYSTEMS}

\author{
Ivanko Alexander Fedorovich ${ }^{1}$, Ivanko Mikhail Alexandrovich ${ }^{2}$, V. Kulikova ${ }^{3}$, Sultanova \\ Yu. ${ }^{4}$ \\ ${ }^{1}$ Professor, Ph.D., Higher School of Press and Media Industry of Moscow Polytechnic \\ University 127550 Russia, Moscow, ul. Pryanishnikova, 2A \\ ${ }^{2}$ Associate Professor, Ph.D., Higher School of Press and Media Industry of Moscow \\ Polytechnic University 127550 Russia, Moscow, ul. Pryanishnikova, 2A \\ ${ }^{3}$ Associate Professor, Candidate of Philology, Higher School of Press and Media Industry of \\ Moscow Polytechnic University 127550 Russia, Moscow, ul. Pryanishnikova, 2A \\ ${ }^{4}$ Senior Lecturer, Higher School of Press and Media Industry of Moscow Polytechnic University \\ 127550 Russia, Moscow, ul. Pryanishnikova, 2A
}

\begin{abstract}
Information technology is widely used in the educational process. To increase the motivation for learning, various methodical methods and means are used. The experience of using the "matrix" information system shows how interest appears to the learning process and all its participants: teachers and students. The article is of interest to all participants of the educational process.
\end{abstract}

Keywords: Information Systems; Educational Process; Information Society; Computer Technologies.

Cite This Article: Ivanko Alexander Fedorovich, Ivanko Mikhail Alexandrovich, V. Kulikova, and Sultanova Yu.. (2018). "MOTIVATION OF STUDYING WITH THE HELP OF INFORMATION SYSTEMS.” International Journal of Research - Granthaalayah, 6(3), 8-14. https://doi.org/10.29121/granthaalayah.v6.i3.2018.1492.

\section{Introduction}

Modern information technologies find the most diverse application in various subject areas of human activity $[1,2]$. Education is such a field of human activity where the most advanced should be used: - the latest achievements of science and technology, both in the humanities and in natural disciplines and spheres of human activity $[4,5]$.

Information systems, computer technologies, social networks have recently covered many aspects of the life of civil society and offer new perspectives and opportunities for people.

In education, distance technologies have recently begun to be used, gaming methods have helped to increase the interest of students and students to study, etc. [3, 7] 
In the Graduate School of Press and Media Industry over the past few years, the information system, known as the "matrix," has been successfully applied.

The main goals and tasks that this information system solves: [9, 10]

- Increased interest in the learning process by both students and teachers;

- Motivation of students to monitor academic progress during the academic semester;

- Increase of control over students' progress on the part of teachers, department and dean's office;

- The validity of assessments of students' knowledge during the intermediate control of academic performance during the semester;

- The reasonableness of assessments of students 'knowledge during the final control of students' knowledge at the end of the semester;

- Verification of students' knowledge of compliance with the declared competencies in the funds of evaluation tools developed by the teachers of the department in accordance with the curricula of the academic disciplines;

- The reasonableness of the assessments in the testing of students for the correspondence of residual knowledge to the declared competencies during the accreditation procedure of the university or institute.

The main interfaces shown in the figures show the capabilities of the MATRIX IC.

Work with the system begins with the login to the system. Teacher for work in the "Matrix" must register in the department of information systems of the University and get a login and password for logging in (authorization process). After entering the system, the teacher enters the menu shown in figure 1.

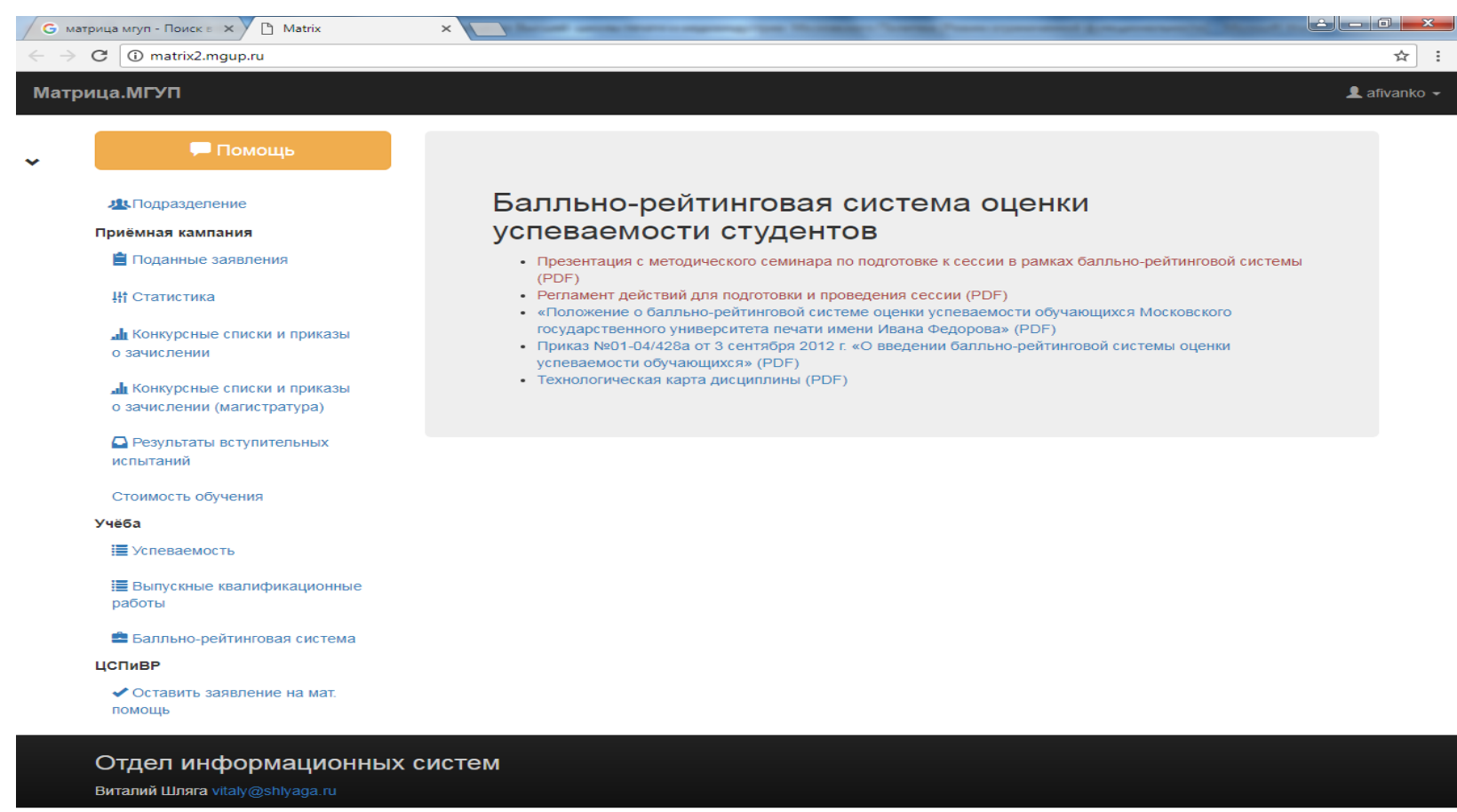

Figure 1: Menu "matrix." 
For the teacher and students, it is important to assess the knowledge with the help of a ratingrating system. As we have said above, all student work and students' knowledge are evaluated at all stages of the educational process: attending lectures, working during practical and laboratory classes, performing independent works and projects, etc. An important stage is the control points for certain sections of the discipline, which represent an intermediate certification. Figure 2 shows the menu, which shows all the disciplines and groups in which the teacher is conducting the lessons[11,12]. Each discipline is associated with a particular group or groups. After entering this menu, there is an immediate opportunity to enter information on a group of students on the days when one or another type of training took place. Figure № 3 shows that all types of classes are taken into account: lectures, practical classes, laboratory works and control points for certain sections of the academic discipline. Presence and work on lectures are counted as "was-nebyl"; work in practical classes is taken into account on a five-point system of assessments, intermediate certification (control points) is taken into account on the scored points from 11satisfactory. up to 20-excellent.

G матрица мгуп - Поиск $\mathrm{x} / \mathrm{C}$ Matrix
$\leftarrow \rightarrow \mathrm{C}$ (i) matrix2.mgup.ru/study/disciplines
Матрица.МГУП

. Помощь Балльно-рейтинговая система

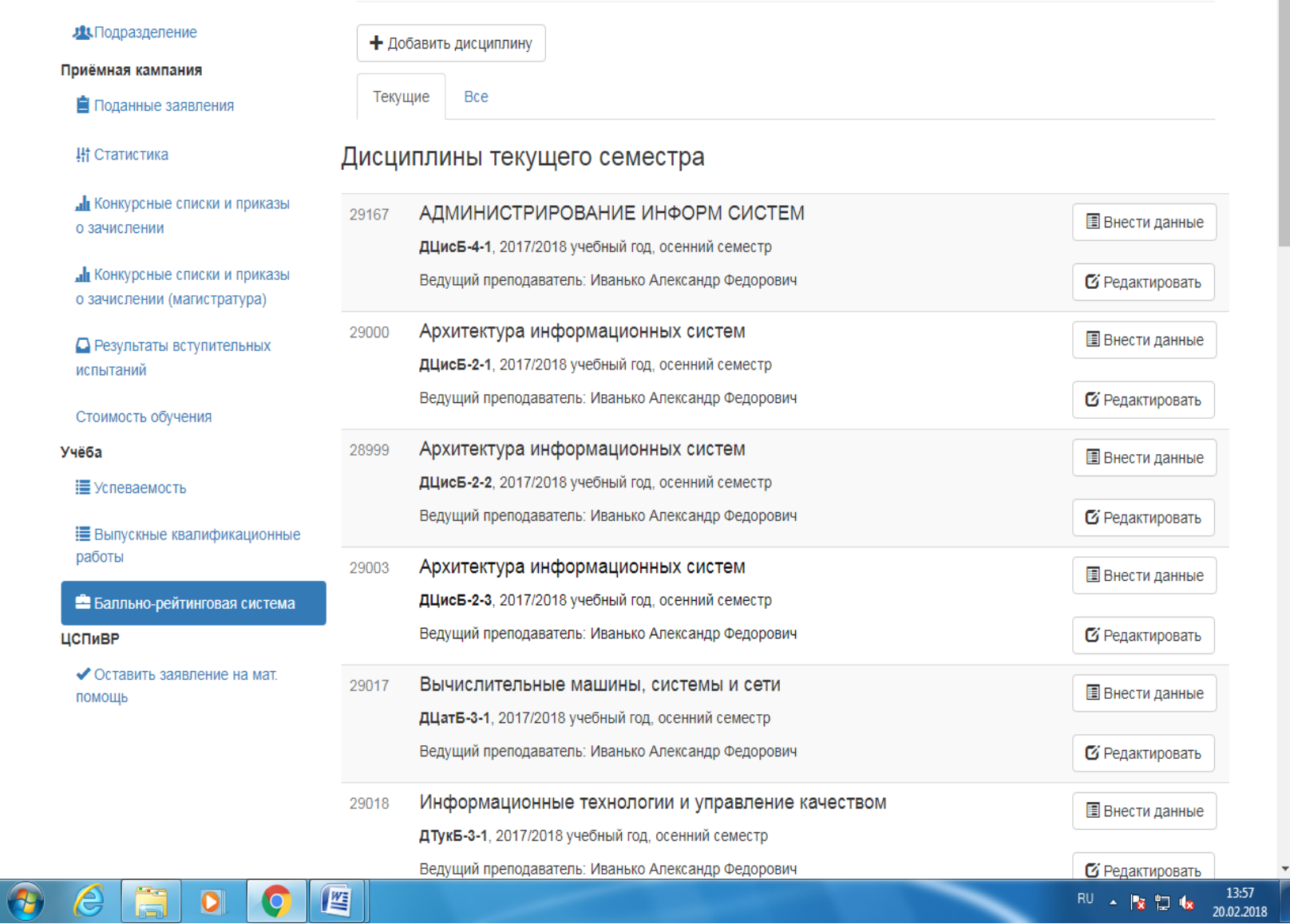

Figure 2: The rating system 


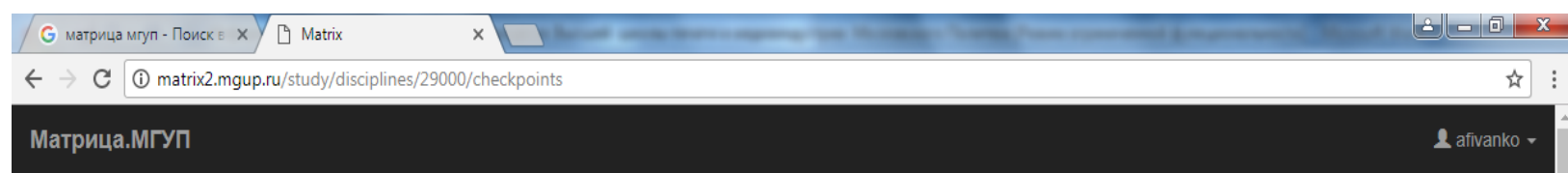

Р Промощь Архитектура инфрормационных систем дцись-2-1

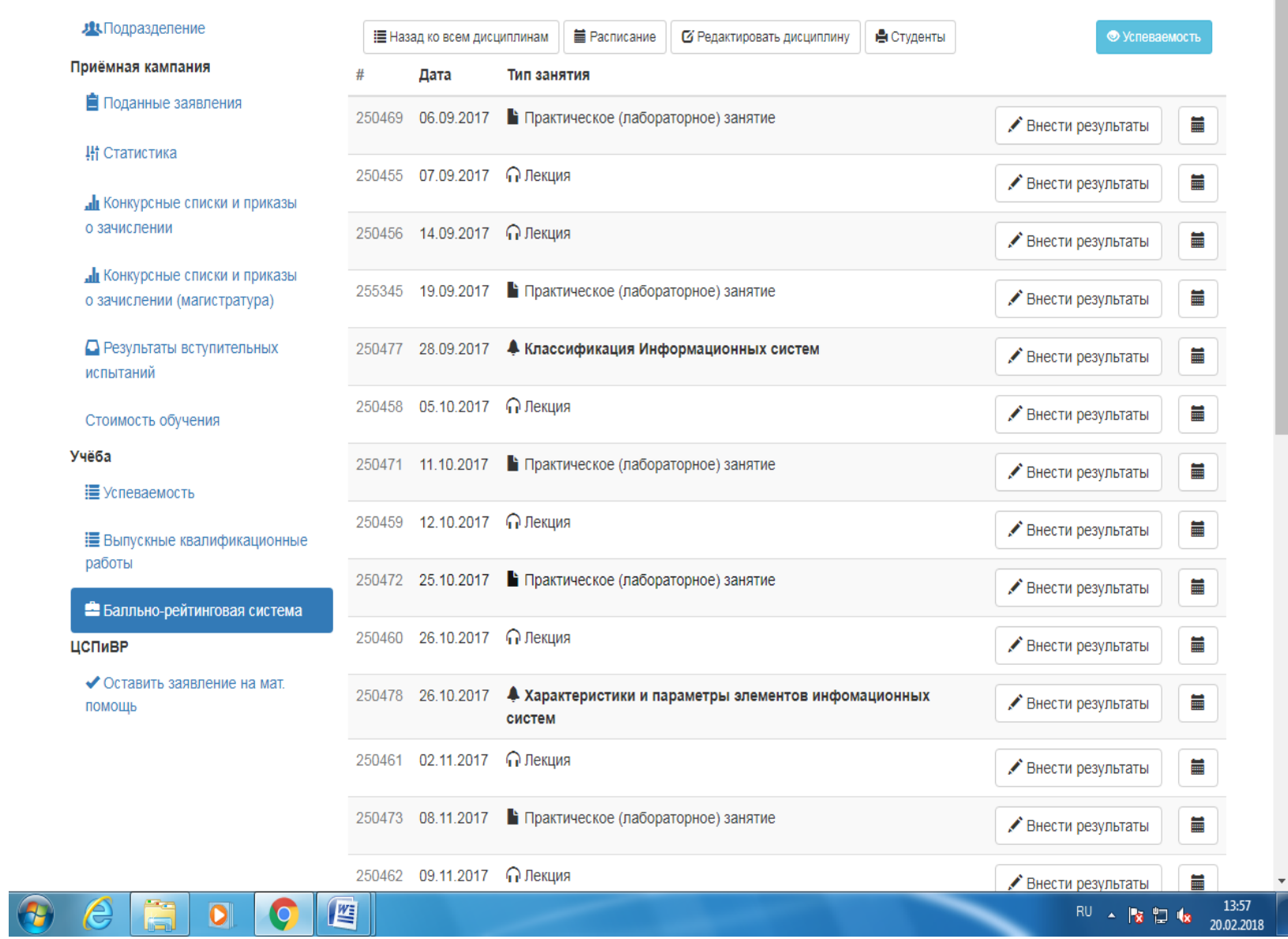

Figure 3: Form for entering the results of students' work for all types of activities

As a result, during the academic semester, the student picks up a certain number of points. For admission to the exam, you need to score 55 points. The maximum score (100 points) can be typed by the student himself or received on the exam, taking into account the points that the teacher can put during the exam. At any time during the semester, the student can see the result of his work in the matrix (Figure 4). At the end of the semester, the resultant student progress sheet appears on the discipline: figure 5 . Which shows how many points each student has scored during the semester. In figure № 6. A list with recommended grades for all students who were admitted before the exam is shown. From this list it can be seen that some students have already scored such a number of points, which corresponds to an excellent rating and such students can be boldly posed as "automatic", because the result of their work during the semester, intermediate certifications convincingly show their conscientious work and quite worthy knowledge. 


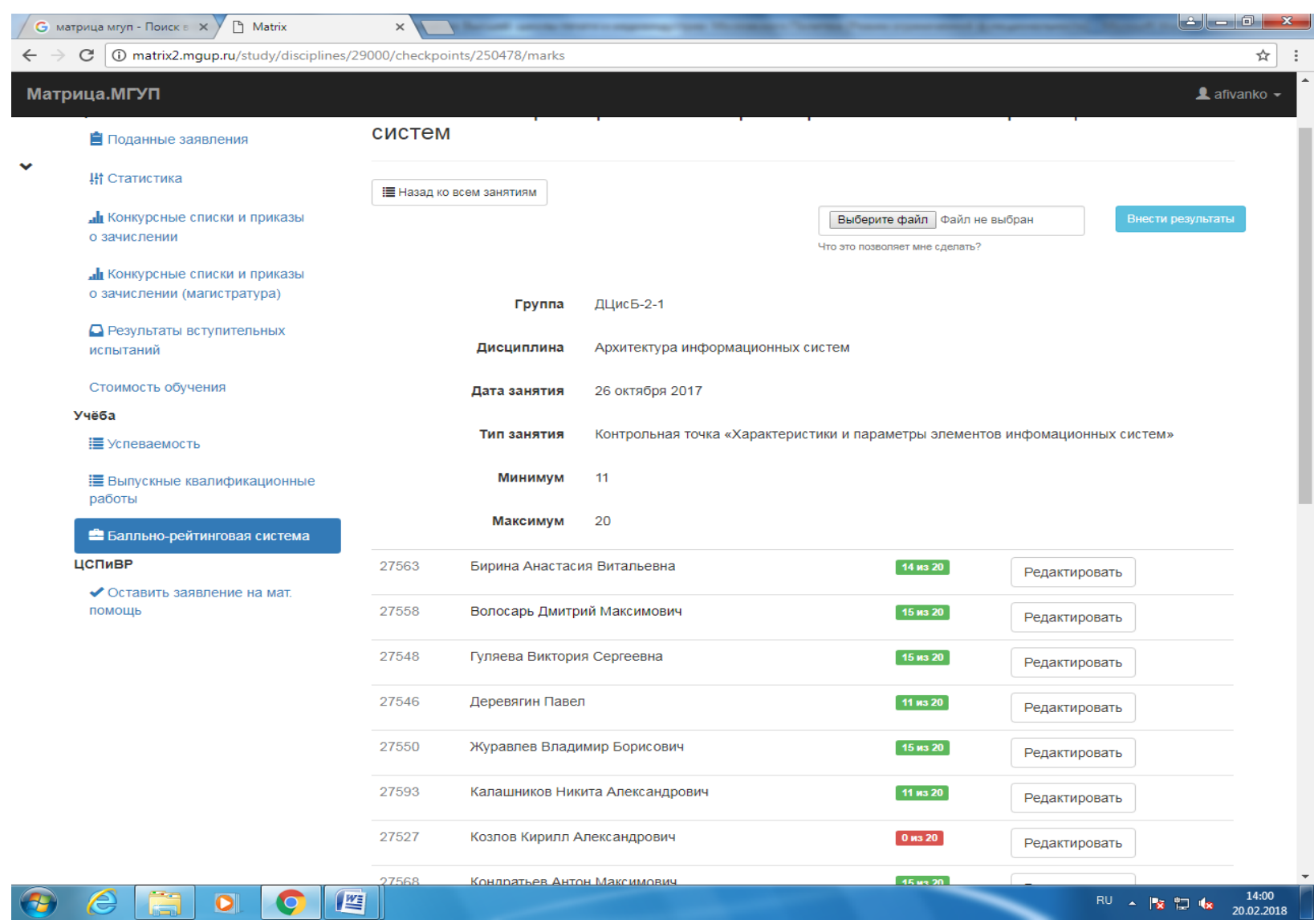

Figure 4: Results of intermediate certification (control point No. 4.)

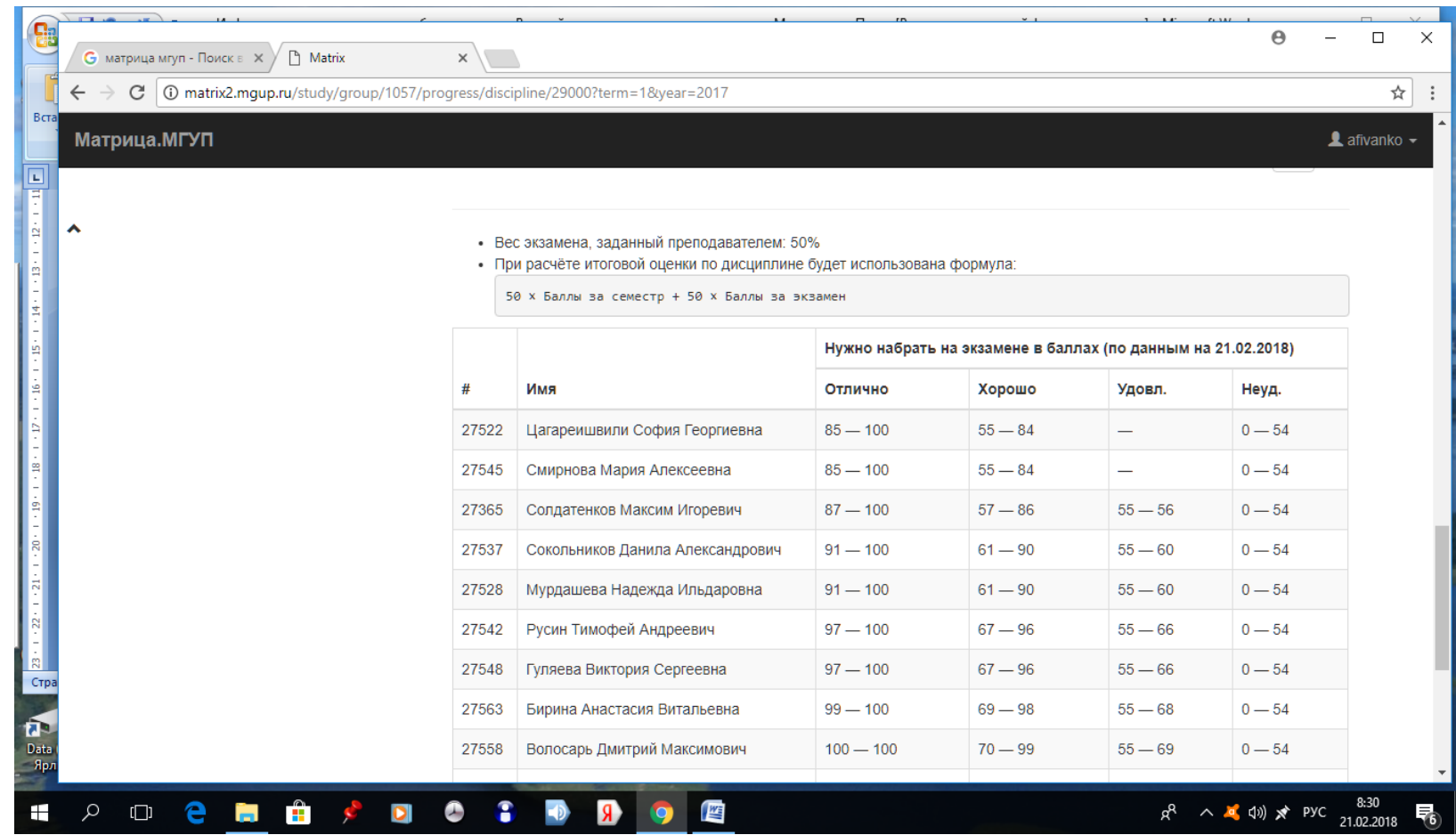

Figure 5: Progress in the discipline "IP Architecture" of the group DTSISB 2-1 


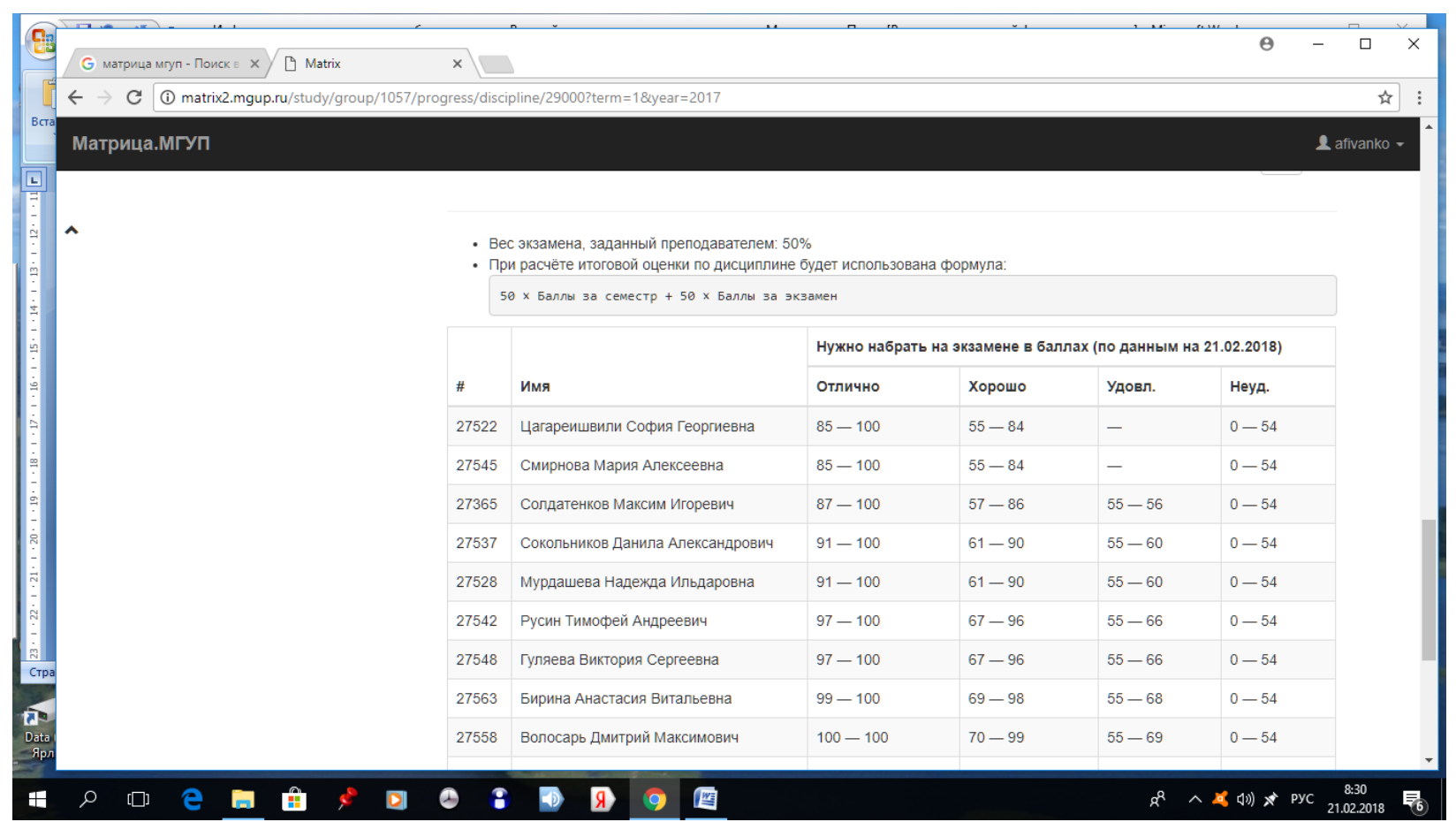

Figure 6: Statement of achievement with the recommended estimates

\section{Conclusions}

Experience in operating the matrix information system shows that both students and teachers positively assessed the introduction of this information system in the educational process. Students have the opportunity in real time to observe their progress in learning and draw the appropriate conclusions. For teachers, working with this information system is an additional burden and it takes time to enter data, to account for the work of students at all stages of the learning process. However, we state that the introduction of this information system or similar motivates students to actively work at all stages of the educational process. As a result, students take exams in disciplines, where this system is introduced to higher grades and this improves the quality of training and promotes mastering all the declared competencies.

\section{References}

[1] Software \& Systems Software products and systems / Collection. № 3 (107), 2014 / Cloud technologies: basic models, applications, concepts and development trends. T.V. Batura, F.A. Murzin, D.F. Seven.

[2] Peter Mell, Timothy Grance The Cloud Computing. Cloud computing https://en.wikipedia.org/wiki/Cloud calculations (date of circulation: 05.10.2016).

[3] Gaming As A Service: Computing clouds for the gaming industry https://habrahabr.ru/company/ruvds/blog/306148/(reference date: 05.10.2016)

[4] Social network VKontakte https://vk.com/.

[5] Ivanchenko D.A. Management of mobile technologies in the information space of a modern university // Higher education in Russia. - 2014. - № 7. - P. 93-100.

[6] Naismith, L., Lonsdale, P., Vavoula, G. \& Sharples, M. (2005) Literature Review in Mobile Technologies and Learning. Report 11, NESTA Futurelab. Bristol: NESTA Futurelab. 
[7] Sharples, M. (Ed., 2007). Big issues in mobile learning: Report of a workshop by the Kaleidoscope Network of Excellence Mobile Learning Initiative. Nottingham, UK: University of Nottingham, Learning Sciences Research Institute.

[8] Universities on Facebook, Available at: https://www.facebook.com/Universities/timeline?ref=page_internal (accessed 12 Novem-ber 2015).

[9] Allen M. An Education in Facebook // Digital culture and education. - 2012. - Vol. 4. - No. 3. - P. 213-225.

[10] History of the development of computer games. Available at: http://cmnews.ru/2014/08/08/istoriya-razvitiya-kompyuternyx-igr/

[11] Pedagogical technologies: Textbook for students of pedagogical specialties / Under the general ed. B.C. Kukushina. - Series "Pedagogical Education". - Moscow: ECC "MarT"; Rostov n / a: Publishing Center "MarT", 2004. - 336 p.

*Corresponding author.

E-mail address: alekfed@ mail.ru/mihaleks@ mail.ru 